Brit. J. prev. soc. Med. (1974), 28, 133-139

\title{
Factors affecting the visiting pattern of geriatric patients in a rural area
}

\author{
K. W. CROSS AND R. D. TURNER \\ Department of Social Medicine, University of Birmingham
}

\begin{abstract}
SUMMARY
For a period of one week, all visitors to Shropshire patients in geriatric units were interrogated about the method, duration, and starting point of their journey to hospital. These data, together with those of the patients, were used to examine the extent to which the duration of hospital stay, and the 'crowfly' distances of patients' and visitors' homes from the hospitals, affected visiting rates. The pronounced effect of the first factor underlines the need to consider separately those patients requiring assessment and rehabilitation from those requiring mainly custodial care when the siting of hospitals for geriatric patients is being planned. The visiting pattern for the former type of patient was not materially affected by the distance of the patient's home from hospital (within a range of 0-32 kilometres), whereas visiting rates for long-stay patients decreased rapidly as distance increased beyond 16 kilometres (10 miles).
\end{abstract}

\section{INTRODUCTION}

The visiting of patients in hospital by relatives and friends is generally considered to be highly desirable. Visiting is seen as an important factor in maintaining the links between patients and the community from which they have been admitted, as well as providing opportunities for hospital staffs to discuss with relatives the condition of the patient and the possibilities of, and requirements for, discharge. In recent years, hospitals have become increasingly flexible as regards the hours during which visitors are allowed on wards. Hospitals accommodating long-stay patients have extended their visiting hours, and at some, visiting is permitted at almost any reasonable time during the day.

The extent to which patients, and especially long-stay patients, are visited is therefore a matter of some concern, and it seems important to identify those factors which have a bearing upon visiting rates. One such factor is the siting of a hospital, and in a study of visiting of long-stay Birmingham patients, McKeown, Cross, and Keating (1971) compared the experience of visitors to geriatric and psychiatric patients resident in units at three district general hospital sites with that of visitors to similar patients in other units sited (usually) nearer the periphery of the city. The mean number of weekly visits per patient was a little greater for the former type of unit; and the duration of travel by car or bus was one-third less and the cost of public transport about half.

However, it seems important to consider the effect of siting, and of other factors, upon the visiting patterns for patients in long-stay hospitals in a rural area where travelling distances are likely to be greater and public transport facilities are likely to be less satisfactory than in a city.

The county of Shropshire was chosen for the present study. This is a predominantly rural area with a population of 337,100 . There are five municipal boroughs and urban districts which together contain 123,000 persons, and nine rural districts containing 214,000 people. Shrewsbury $(56,200$ population) is the only major town in the area at present; a new town is being developed at Telford.

In this paper we shall be concerned with visits to geriatric patients and the siting of each of the nine geriatric units within the county, as shown in the Figure. The units differ in size, admission policies, and accessibility to their catchment areas. For reasons which will be discussed later, it is necessary to distinguish between those units which are primarily, or to a substantial degree, used for assessing the patient's needs and their subsequent rehabilitation, and those which are largely concerned with providing custodial care. 


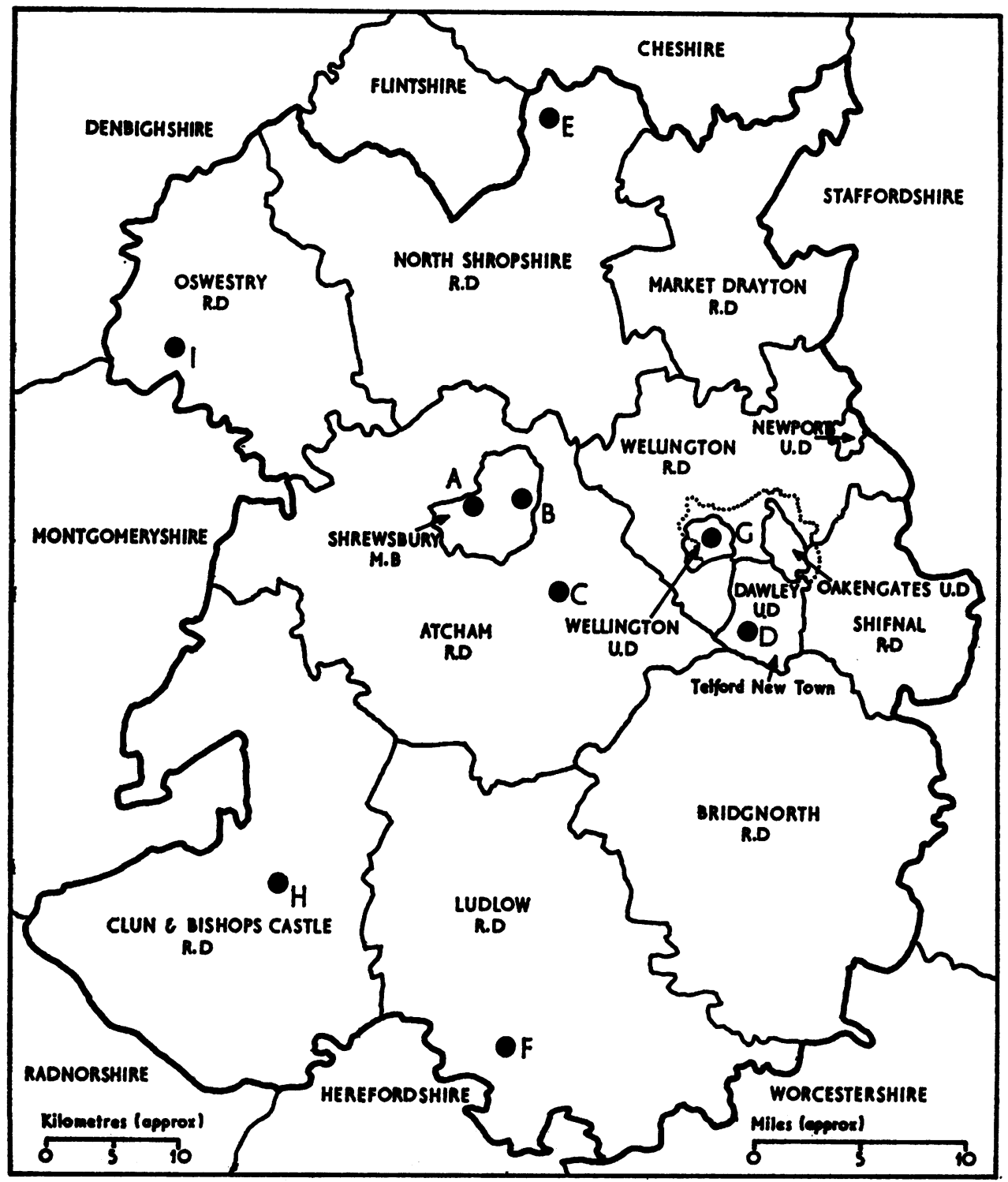

Froune Geriatric units in Shropshire.

\section{'ASSESSMENT' UNITS}

Unit $A$ is a 25-bedded ward for female patients within the district general hospital, which is situated on the ring-road around Shrewsbury; it is primarily an assessment unit and few patients stay longer than one month. Hospital B, which has 53 beds, is also situated on the outskirts of Shrewsbury, but not on a main road, and bus services from districts outside Shrewsbury are infrequent. Hospital C, with 133 geriatric beds, is situated in a rural area 5 miles from, and on a main road to, Shrewsbury.

\section{'Custodial' UNITS}

Unit D, with 86 geriatric beds, forms the larger part of a hospital sited near the southern periphery of the developing area of Telford New Town. Hospital E, with 96 beds, is situated in a market town at the northern point of the county, and hospital F, with 33 beds for each sex, is sited on the outskirts of a market town in the southern part of the county; most of the patients in these hospitals are residents of the towns (populations approximately 7,000 persons) and the surrounding rural 
areas. Unit $\mathrm{G}$, with 50 beds, is sited on the outskirts of a town of 17,000 people to the east of the county. Hospital $\mathrm{H}$, with 12 beds for each sex, is located in a small borough (population approximately 1,500 persons) near the centre of a predominantly rural area. Hospital I, with only 18 female beds, serves a rural area to the west of the county.

\section{MeTHods}

The same method of data collection has been employed as that used in the Birmingham study (McKeown et al., 1971), viz., a form was completed by each visitor on each visit which took place during one week (19-25 June 1972) to all the patients in the nine hospitals. In choosing the week of study, care was taken to avoid state, works, or school holidays. Items recorded included name, address and relationship of visitor to patient; date and time of visit; mode of transport, and duration, and, where public transport was used, the cost, of the one-way journey to the hospital. The hospital staff, mainly nursing staff, took responsibility for ensuring that each visitor completed a form; there were no recorded refusals.

After the survey week a form was completed for each patient on which was recorded the address and date of admission and, for those patients who had not been visited during the week of the survey, details of any known relatives and any reasons why the patient was not visited.

The extent to which visiting takes place during a period can be measured by the number of visits made and by the number of visitors involved, and in what follows, use is made of both these measures.

\section{Visits}

\section{Results}

Table I shows the frequency of visits to the 511 patients in geriatric units during the week of the survey. About four-fifths of the patients were visited, and on average each patient had five visits; one quarter of the patients had more than seven visits. Those hospitals with outstandingly different results from this average were hospitals A, B, D, and $\mathbf{E}$.

Hospital $\mathbf{A}$ had the highest average number of visits per patient (12.9); all patients were visited and $71 \%$ of them had more than seven visits during the week. As mentioned previously, this unit is an assessment unit for women, and their length of stay in hospital is relatively very short. Patients in hospital B received on average eight visits, and only
TABLE I

SUMMARY OF VISITS MADE TO SHROPSHIRE PATIENTS IN GERIATRIC UNITS

\begin{tabular}{|c|c|c|c|c|c|c|}
\hline \multirow[b]{2}{*}{ Hospital } & \multirow{2}{*}{$\begin{array}{c}\text { No. } \\
\text { of } \\
\text { Patients }\end{array}$} & \multirow[b]{2}{*}{$\begin{array}{l}\text { No. of } \\
\text { Visits }\end{array}$} & \multirow{2}{*}{$\begin{array}{c}\text { Average } \\
\text { No. of } \\
\text { Visits per } \\
\text { Patient }\end{array}$} & \multicolumn{3}{|c|}{$\begin{array}{c}\text { Percentage of } \\
\text { Patients receiving }\end{array}$} \\
\hline & & & & $\begin{array}{l}\text { No } \\
\text { Visits }\end{array}$ & $\begin{array}{c}1-7 \\
\text { Visits }\end{array}$ & $\begin{array}{l}8+ \\
\text { Visits }\end{array}$ \\
\hline $\begin{array}{l}\mathbf{A} \\
\mathbf{B} \\
\mathbf{C} \\
\mathbf{D} \\
\mathbf{E} \\
\mathbf{F} \\
\mathbf{G} \\
\mathbf{H} \\
\mathbf{I}\end{array}$ & $\begin{array}{r}28 \\
53 \\
101 \\
74 \\
94 \\
68 \\
50 \\
25 \\
18\end{array}$ & $\begin{array}{l}362 \\
425 \\
536 \\
248 \\
290 \\
447 \\
225 \\
152 \\
109\end{array}$ & $\begin{array}{r}12 \cdot 9 \\
8 \cdot 0 \\
5 \cdot 3 \\
3 \cdot 4 \\
3 \cdot 1 \\
6 \cdot 6 \\
4 \cdot 5 \\
6 \cdot 1 \\
6 \cdot 1\end{array}$ & $\begin{array}{r}0 \\
8 \\
4 \\
30 \\
29 \\
12 \\
8 \\
16 \\
11\end{array}$ & $\begin{array}{l}\mathbf{2 9} \\
\mathbf{5 8} \\
\mathbf{7 1} \\
\mathbf{5 8} \\
\mathbf{5 8} \\
\mathbf{5 3} \\
\mathbf{7 2} \\
\mathbf{5 2} \\
\mathbf{5 1}\end{array}$ & $\begin{array}{l}71 \\
34 \\
25 \\
12 \\
13 \\
35 \\
20 \\
32 \\
38\end{array}$ \\
\hline All hospitals & 511 & 2,794 & $5 \cdot 5$ & 18 & 57 & 25 \\
\hline
\end{tabular}

$8 \%$ were not visited; a large proportion of patients in this hospital had been in hospital less than 2 months. Only $4 \%$ of patients in hospital $\mathrm{C}$ were not visited, but on the average patients received only five visits during the week.

The mean number of visits per patient at the 'custodial' units ranged from $3 \cdot 1$ (hospital E) to $6 \cdot 6$ (hospital F). Nearly one-third of the patients in hospitals $\mathrm{D}$ and $\mathrm{E}$ were not visited at all during the week. Hospitals $\mathrm{F}, \mathrm{H}$, and I had relatively high mean values for hospitals of this type; about one-third of the patients received more than seven visits during the week.

The distribution of visits by mode of transport is shown in Table II. For all hospitals, three-quarters of the visits were made by car, a much higher

TABLE II

PERCENTAGE DISTRIBUTION OF VISITS BY MODE OF TRANSPORT

\begin{tabular}{|c|c|c|c|c|c|}
\hline Hospital & Car & $\begin{array}{l}\text { Public } \\
\text { Transport } \\
\text { only }\end{array}$ & $\begin{array}{l}\text { Foot/ } \\
\text { Cycle } \\
\text { only }\end{array}$ & Other & Totals \\
\hline $\mathbf{A}$ & 91 & 5 & 2 & 2 & 100 \\
\hline B & 79 & 7 & 11 & 3 & 100 \\
\hline C & 83 & 13 & 3 & 1 & $\begin{array}{l}(420) \\
100\end{array}$ \\
\hline D & 73 & 13 & 11 & 3 & 100 \\
\hline $\mathbf{E}$ & 84 & 3 & 9 & 4 & (248) \\
\hline $\mathbf{F}$ & 58 & 5 & 35 & 2 & 100 \\
\hline $\mathbf{G}$ & 56 & 23 & 17 & 4 & $\begin{array}{l}(447) \\
100\end{array}$ \\
\hline $\mathbf{H}$ & 53 & 2 & 44 & 1 & (225) \\
\hline I & 82 & 11 & 5 & 2 & $\begin{array}{l}100 \\
(109)\end{array}$ \\
\hline All hospitals & 75 & 9 & 14 & 2 & $\begin{array}{r}100 \\
(2,794)\end{array}$ \\
\hline
\end{tabular}


proportion than that $(49 \%)$ found in the Birmingham survey. More than four-fifths of the visits to patients in hospitals $\mathrm{A}, \mathrm{B}$, and $\mathrm{C}$ combined were made by car, and hospitals $E$ and $I$ also had proportions exceeding $80 \%$. Three hospitals, F, G, and $\mathrm{H}$, had relatively small proportions of visits made by car; relatively large proportions of visits to patients in hospitals $\mathrm{F}$ and $\mathrm{H}$ were made on foot or by bicycle, and one quarter of the visits to patients in hospital $G$ were by public transport. Only $9 \%$ of all visits were made by public transport (as compared with $39 \%$ of the visits to Birmingham patients), and this low proportion presumably reflects the lack of such transport in the rural parts of the county.

The mean times of travelling the one-way journey to the hospitals by the three methods of transport, car, public transport, and foot/bicycle, were calculated. The overall average for car journeys was 30 minutes, and it is interesting that, in the Birmingham study, the mean travelling time by car to geriatric units other than those at the district general hospital sites was virtually the same as this Shropshire figure. The hospital mean times for visits by public transport ranged from 34 to 49 minutes, an overall mean of about 39 minutes. Visitors travelling by public transport were asked to state the cost of the journey that they had just completed, and the overall mean cost was $15 \mathrm{p}$. The average time taken to walk or cycle was 15 minutes, which agrees closely with the corresponding result of the Birmingham study.

\section{Factors affecting Visiting Patterns}

The above results give a general picture of the extent to which patients in various hospitals were visited. The differences between these hospital visiting rates could be due to several interrelated factors, including the length of stay of patients, the siting of the hospitals, and the manner in which visitors travelled.

LENGTH OF STAY. We first examine how visiting rates varied for patients in various length-of-stay groups. For this part and for the remainder of the study those patients who died during the week of the survey have been excluded because the visiting pattern to these patients is likely to be atypical. We also exclude those visitors (and the patients visited by them) who travelled from an address other than their own home, and those who failed to give the address from which they had travelled.

Table III first shows the proportions of patients in each length-of-stay group who were not visited during the week. There was a general tendency for the proportion to increase with length of stay: only one patient was not visited out of the 91 who had been in hospital less than one month at the time of the survey, whereas about one-third of those patients who had been in residence two years or more were not visited.

The mean number of visits per patient decreased from 8.8 for patients who had been in residence for less than one month to 6.5 for those with a length of stay of between three and six months. The mean for the ' 6 months- 1 year' group was much lower at 3.9 , and thereafter little reduction in the mean was found until the ' 3 years and over' group which had a value of only $2 \cdot 5$. A similar pattern was found when the number of visits was related to the number of patients visited in each length-of-stay category.

Finally, the number of visitors to each group of patients is shown, and it is of interest that the mean number of visits per visitor was the same $(1 \cdot 6)$ for the first two length-of-stay categories, was only slightly less $(1 \cdot 5)$ for the five categories ' 2 months-3 months' to ' 2 years-3 years', and decreased to $1 \cdot 3$ for each of the two longest length-of-stay groups.

TABLE III

VISITING PATTERNS BY LENGTH OF STAY OF PATIENT

\begin{tabular}{|c|c|c|c|c|c|c|c|c|c|}
\hline \multicolumn{3}{|c|}{ Length of Stay } & $\begin{array}{l}\text { Total } \\
\text { no. of } \\
\text { Patients }\end{array}$ & $\begin{array}{c}\text { Percent } \\
\text { non-visited }\end{array}$ & $\begin{array}{l}\text { No. of } \\
\text { Visits }\end{array}$ & $\begin{array}{l}\text { Mean no. } \\
\text { of Visits/ } \\
\text { Patient }\end{array}$ & $\begin{array}{l}\text { Mean no. of } \\
\text { Visits/Patient } \\
\text { visited }\end{array}$ & $\begin{array}{l}\text { No. of } \\
\text { Visitors }\end{array}$ & $\begin{array}{l}\text { Mean no. } \\
\text { of Visits/ } \\
\text { Visitor }\end{array}$ \\
\hline $\begin{array}{l}<1 \text { month } \\
1-\ldots \\
2-\ldots \\
3-\ldots \\
6-\ldots \\
1 \text { year }- \\
2 \text { years - } \\
3 \text { years - } \\
5 \text { years and }\end{array}$ & $\begin{array}{l}\ldots \\
\cdots \\
\cdots \\
\cdots \\
\cdots \\
\ddot{\text { over }}\end{array}$ & $\begin{array}{l}\cdots \\
\cdots \\
\cdots \\
\cdots \\
\cdots \\
\cdots\end{array}$ & $\begin{array}{l}91 \\
51 \\
22 \\
55 \\
52 \\
72 \\
41 \\
44 \\
46\end{array}$ & $\begin{array}{r}1 \cdot 1 \\
7 \cdot 8 \\
9 \cdot 1 \\
3 \cdot 6 \\
19 \cdot 2 \\
16 \cdot 7 \\
31 \cdot 7 \\
34 \cdot 1 \\
30 \cdot 4\end{array}$ & $\begin{array}{l}804 \\
382 \\
147 \\
360 \\
204 \\
248 \\
162 \\
110 \\
120\end{array}$ & $\begin{array}{l}8 \cdot 8 \\
7 \cdot 5 \\
6 \cdot 7 \\
6 \cdot 5 \\
3 \cdot 9 \\
3 \cdot 4 \\
4 \cdot 0 \\
2 \cdot 5 \\
2 \cdot 6\end{array}$ & $\begin{array}{l}8 \cdot 9 \\
8 \cdot 1 \\
7 \cdot 4 \\
6 \cdot 8 \\
4 \cdot 9 \\
4 \cdot 1 \\
5 \cdot 8 \\
3 \cdot 8 \\
3 \cdot 8\end{array}$ & $\begin{array}{r}496 \\
236 \\
97 \\
233 \\
136 \\
149 \\
110 \\
85 \\
94\end{array}$ & $\begin{array}{l}1 \cdot 6 \\
1 \cdot 6 \\
1 \cdot 5 \\
1 \cdot 5 \\
1 \cdot 5 \\
1 \cdot 5 \\
1 \cdot 5 \\
1 \cdot 3 \\
1 \cdot 3\end{array}$ \\
\hline Totals & $\cdots$ & $\cdots$ & 474 & $15 \cdot 4$ & 2,537 & $5 \cdot 4$ & $6 \cdot 3$ & 1,636 & $1 \cdot 5$ \\
\hline
\end{tabular}


Distance. Having established that length of stay of patients has a pronounced effect upon visiting rates, we now consider the effect of (1) the distances of patients' homes (addresses from which they were admitted to hospital) from hospital; and (2) the distances visitors had to travel. These 'crow-fly' distances were computed from the grid references of the hospitals and of the addresses given by patients and visitors.

The effect of the former distance factor has been examined by first allocating the patients to four length-of-stay groups (chosen with due regard to the differences referred to above) and to four distance groups of 8 kilometres each. The frequency distributions of visits made to patients in each of these 16 sub-sets were then obtained, and Table IV gives the proportions of patients who received more than two visits during the week. The latter yardstick was chosen so that reliable proportions would be obtained for patients in the longest length-of-stay group ( 3 years and over); it has been shown that these patients received only 2.5 visits on the average.

The table shows that proportions for patients who had been in hospital for less than 2 months did not decrease with increasing distance; and the same was true of patients in the 2-6 months lengthof-stay group. For patients who had been in hospital for between 6 months and 3 years, the proportion decreased for distances greater than 16 kilometres (10 miles), and only one quarter of those patients whose homes were more than 24 kilometres (15 miles) from the hospital received more than two visits. The same pattern emerged for patients whose stay in hospital was 3 years or over, and less than one-fifth of these patients whose homes were more than 16 kilometres (10 miles) from hospital received more than two visits.

We may similarly examine the proportion of patients who were not visited at all during the week, distinguishing between those whose homes were less than or equal to 16 kilometres $(10$ miles) from hospital and those with homes at greater distances than this. Proportions for the two short-stay groups (Table V) refer to very small numbers of nonvisited patients so that no conclusions can be drawn. As regards each of the other two length-of-stay groups, the proportion of patients whose home addresses were more than 16 kilometres from hospital and who were not visited greatly exceeded the corresponding proportion for patients who lived nearer hospital.

TABLE IV

PROPORTIONS OF PATIENTS WHO RECEIVED MORE THAN TWO VISITS DURING THE WEEK

\begin{tabular}{|c|c|c|c|c|c|c|c|c|c|c|}
\hline \multirow{3}{*}{\multicolumn{3}{|c|}{$\begin{array}{l}\text { Distance of Patient's } \\
\text { Home Address from } \\
\text { Hospital (km) }\end{array}$}} & \multicolumn{6}{|c|}{ Length of Stay of Patient } & & \\
\hline & & & \multicolumn{2}{|c|}{ Less than 2 months } & \multicolumn{2}{|c|}{2 months - } & \multicolumn{2}{|c|}{6 months - } & \multicolumn{2}{|c|}{3 years +} \\
\hline & & & $\begin{array}{c}\text { No. of } \\
\text { Patients }\end{array}$ & $>2$ Visits & $\begin{array}{l}\text { No. of } \\
\text { Patients }\end{array}$ & $>2 \underset{\%}{2 \text { Visits }}$ & $\begin{array}{c}\text { No of } \\
\text { Patients }\end{array}$ & $>2 \underset{\%}{2 \text { Visits }}$ & $\begin{array}{c}\text { No. of } \\
\text { Patients }\end{array}$ & $>2 \underset{\%}{2}$ Visits \\
\hline $\begin{array}{l}0-8 \\
9-16 \\
17-24 \\
25+\end{array}$ & $\begin{array}{l}\cdots \\
\cdots \\
\cdots\end{array}$ & $\begin{array}{l}. \\
\because \\
\cdots\end{array}$ & $\begin{array}{l}64 \\
28 \\
27 \\
23\end{array}$ & $\begin{array}{l}88 \\
71 \\
86 \\
88\end{array}$ & $\begin{array}{l}33 \\
14 \\
16 \\
14\end{array}$ & $\begin{array}{l}72 \\
71 \\
81 \\
71\end{array}$ & $\begin{array}{l}87 \\
44 \\
13 \\
21\end{array}$ & $\begin{array}{l}53 \\
58 \\
46 \\
24 \\
\end{array}$ & $\begin{array}{r}46 \\
23 \\
9 \\
12\end{array}$ & $\begin{array}{l}39 \\
39 \\
22 \\
17\end{array}$ \\
\hline All dist & $\ldots$ & . & 142 & 85 & 77 & 73 & 165 & 50 & 90 & 35 \\
\hline
\end{tabular}

TABLE V

PERCENTAGe OF PATIENTS WHO WERE NOT VISITED DURING THE WEEK

\begin{tabular}{|c|c|c|c|c|c|c|c|c|}
\hline \multirow{2}{*}{\multicolumn{5}{|c|}{$\begin{array}{c}\text { Distance of Patient's Home Address from } \\
\text { Hospital (km) }\end{array}$}} & \multicolumn{4}{|c|}{ Length of Stay of Patient } \\
\hline & & & & & \multirow{2}{*}{$\frac{<2 \text { months }}{3}$} & \multirow{2}{*}{$\frac{2 \text { months - }}{8}$} & \multirow{2}{*}{$\frac{6 \text { months }-}{18}$} & \multirow{2}{*}{$\frac{3 \text { years }+}{29}$} \\
\hline $0-16 \quad \ldots$ & . & .. & . & .. & & & & \\
\hline $16+\ldots$ & . & . & $\because$ & .. & 4 & 0 & 32 & 38 \\
\hline All distances & .. & . & . & .. & 4 & 5 & 21 & 32 \\
\hline
\end{tabular}


TABLE VI

PERCENTAGE DISTRIBUTIONS OF VISITORS BY DISTANCE TRAVELLED TO VISIT PATIENTS, GROUPED BY LENGTH OF STAY

\begin{tabular}{|c|c|c|c|c|c|c|c|c|}
\hline & & & & \multicolumn{4}{|c|}{ Length of Stay of Patient } & \multirow[b]{2}{*}{ All Patients } \\
\hline \multicolumn{4}{|c|}{ Distance Travelled (km) } & $<2$ months & 2 months - & 6 months - & $3 \underset{\%}{3 \text { years }}+$ & \\
\hline $\begin{array}{l}0-8 \\
9-16 . \\
17-24 \\
25-32 \\
33-40 \\
41+. .\end{array}$ & 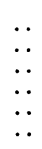 & $\begin{array}{l}. . \\
. \\
. \\
. .\end{array}$ & $\begin{array}{l}. \\
\because \\
\because \\
\because \\
.\end{array}$ & $\begin{array}{r}42.8 \\
13.9 \\
18.6 \\
9.1 \\
5.6 \\
10.0\end{array}$ & $\begin{array}{r}44 \cdot 2 \\
18 \cdot 8 \\
19 \cdot 1 \\
7 \cdot 0 \\
2 \cdot 1 \\
8 \cdot 8\end{array}$ & $\begin{array}{r}50 \cdot 9 \\
24 \cdot 3 \\
8 \cdot 3 \\
5 \cdot 1 \\
4 \cdot 8 \\
6 \cdot 6\end{array}$ & $\begin{array}{r}60.9 \\
20.1 \\
5.0 \\
6.7 \\
3.9 \\
3.4\end{array}$ & $\begin{array}{r}47.0 \\
18.1 \\
14 \cdot 7 \\
7.5 \\
4.5 \\
8.2\end{array}$ \\
\hline Totals & .. & .. & .. & $\begin{array}{r}100 \cdot 0 \\
(732)\end{array}$ & $\begin{array}{r}100 \cdot 0 \\
(330)\end{array}$ & $\begin{array}{r}100 \cdot 0 \\
(395)\end{array}$ & $\begin{array}{r}\begin{array}{r}100 \cdot 0 \\
(179)\end{array} \\
\text { (179) }\end{array}$ & $\begin{array}{l}100 \cdot 0 \\
(1,636)\end{array}$ \\
\hline No. of & & .. & .. & 142 & 77 & 165 & 90 & 474 \\
\hline
\end{tabular}

The effect on visiting rates of the distances visitors have to travel is more difficult to demonstrate, since we have no information regarding the number of relatives and friends who were potential visitors to each patient. Data are available only for those who actually visited patients during the week of the study and hence there are no means of estimating how many potential visitors failed to visit and for what reason. It is possible, however, to examine the proportions of visitors who travelled various distances in order to determine the effect of distance on the number of visits made by individual visitors. These are given separately for patients in the four length-of-stay groups in Table VI.

The distribution for all patients shows that nearly half the visitors travelled 8 kilometres $(5$ miles) or less, about two-thirds travelled 16 kilometres (10 miles) or less, and one-fifth travelled more than 15 miles. The proportion of visitors who travelled 10 miles or less increased from $56.7 \%$ for visitors to patients in the short-stay group to $81 \%$ for visitors to patients who had been in hospital 3 years or more. Conversely, $15.6 \%$ of visitors to short-stay patients made journeys of over 20 miles as compared with only $7 \cdot 3 \%$ of visitors to long-stay patients.
The effect of distance is also evident by conssidering the proportions of visitors from various distances who visited patients more than once during the week. Table VII shows that of the visitors who travelled 10 miles or less, $32 \%$ made two or more visits compared with $22 \%$ of those visitors who travelled between 10 and 20 miles and with $11 \%$ of those who travelled more than 20 miles. These proportions are similar for each patient length-ofstay group, except the 3 years and over group; only $21 \%$ of visitors who travelled 10 miles or less to patients in this category made more than one visit, and the numbers of visitors from greater distances are too small to make the proportions meaningful.

\section{Discussion}

The importance of length of stay of geriatric patients in determining the visiting rate for a hospital has been clearly established. Only five short-stay (less than 2 months) patients had no visitors and, on average, each short-stay patient had five visitors and eight visits during the week. In contrast, one-third of patients who had been in

TABLE VII

PERCENTAGE OF VISITORS WHO MADE MORE THAN ONE VISIT DURING WEEK BY DISTANCE TRAVELLED AND LENGTH OF STAY OF PATIENT

\begin{tabular}{|c|c|c|c|c|c|c|c|c|}
\hline \multirow{2}{*}{\multicolumn{3}{|c|}{ Distance Travelled (km) }} & \multicolumn{2}{|c|}{ Visitors } & \multicolumn{4}{|c|}{ Length of Stay of Patient } \\
\hline & & & Total No. & $\begin{array}{c}\text { \% making } 2 \text { or } \\
\text { more Visits }\end{array}$ & $<2$ months & 2 months - & 6 months - & 3 years + \\
\hline $\begin{array}{l}0-16 \ldots \\
17-32 \\
33+\ldots\end{array}$ & $\begin{array}{l}\cdots \\
\cdots \\
\cdots\end{array}$ & $\begin{array}{l}. \\
. \\
\end{array}$ & $\begin{array}{r}1,065 \\
363 \\
208\end{array}$ & $\begin{array}{l}32 \\
22 \\
11\end{array}$ & $\begin{array}{l}36 \\
24 \\
15 \\
\end{array}$ & $\begin{array}{l}30 \\
24 \\
-\end{array}$ & $\begin{array}{r}34 \\
19 \\
7\end{array}$ & $\left(\frac{21}{15}\right)$ \\
\hline All distar & .. & .. & 1,636 & 27 & 29 & 25 & 29 & 17 \\
\hline
\end{tabular}

Percentages in parentheses are based on small numbers of visitors 
hospital 3 years or longer were not visited, and those who were visited had, on average, two visitors and four visits. Thus any attempt to measure the effect of other factors upon visiting rates for geriatric patients must take account of their length-of-stay structure.

The effect of distance has been demonstrated by examining how visiting rates varied with $(a)$ the distance of the patient's home address from hospital and (b) the distances visitors travelled to the hospital. For patients who had been in hospital for less than 6 months there was no evidence of any decrease in the proportion of patients receiving more than two visits with increasing distance between patient's home and hospital (over the range 0-32 kilometres). On the other hand, for patients with durations of stay of 6 months or more this proportion decreased for distances greater than 16 kilometres (10 miles). The proportion of these patients who were not visited at all during the week was much higher for those whose homes were more than 10 miles from hospitals.

As regards the frequency of visiting in relation to distance travelled by the visitors, it was found that the proportion of visitors who travelled less than 16 kilometres (10 miles) and who visited patients more than once during the week was about three times as great as the corresponding proportion for visitors travelling more than 32 kilometres (20 miles). The geographical disposition of potential visitors in relation to a hospital was unknown, as was the availability or otherwise of convenient methods of transport for each visitor. However, the proportion $(43 \%)$ of visitors who travelled distances greater than 16 kilometres (10 miles) to visit shortstay patients was almost twice the corresponding proportion $(23 \%)$ for visitors to patients with durations of stay of 6 months or more. This finding suggests that potential visitors living at relatively long distances from the hospitals were more pre- pared to make the effort to visit short-stay patients than were those visitors at similar distances with long-stay patients to visit. However, units for longstay patients are well distributed throughout the county (Figure) so that these patients tended to be in hospitals located relatively near to their relatives and friends; $78 \%$ of such patients were in hospitals within 16 kilometres (10 miles) of their homes. On the other hand, short-stay patients were more likely to be in hospitals with assessment facilities available but further removed from the patients' homes, as is evident from the fact that only $63 \%$ of such patients were in hospitals within 16 kilometres of their own homes.

These results have a bearing upon the siting of hospitals and units for geriatric patients in that (1) it is necessary to distinguish between patients requiring assessment and rehabilitation from those requiring custodial care; and (2) from the point of view of visiting, the former category of geriatric patients can be accommodated within any reasonable distance (up to 32 kilometres) of the community from which he or she was admitted, whereas longstay patients need to be accommodated in units within 16 kilometres (10 miles) of their own homes and of their relatives and friends.

We are indebted to the nursing staffs and administrators of the Shropshire hospitals; and to Miss Ida Giles and Mrs. Betty Mann who assisted with the collection and processing of the data. Our thanks are also due to Mr. R. Lancaster and Mrs. Angela Henze for writing the computer programs.

\section{REFERENCES}

McKeown, T., Cross, K. W., and Keating, D. M. (1971). Influence of hospital siting on patient visiting. Lancet, 2, 1082. 